\title{
Comparing the effect of various pipe materials on biofilm formation in chlorinated and combined chlorine-chloraminated water systems
}

\author{
Maggy NB Momba* and N Makala \\ Department of Biochemistry and Microbiology, University of Fort Hare, P/Bag x 1314, Alice 5700, South Africa
}

\begin{abstract}
To compare the effect of various pipe materials on biofilm formation, surface water was used as the test water source; plastic-based pipe materials (polyvinyl chloride-PVC, unplasticised polyvinyl chloride-UPVC, medium density polyethylene-MDPE) and cement-based pipe materials (cement and asbestos cement) are commonly used in drinking water distribution systems in South Africa as test pipe materials. Disinfection was performed using $c a 2.5 \mathrm{mg} \cdot \ell^{-1}$ initial chlorine followed by $c a 1.5 \mathrm{mg} \cdot \ell^{-1}$ monochloramine. The evaluation of the process relied on attached coliforms and heterotrophic plate count bacteria.

General data indicated the colonisation of all test pipe materials by micro-organisms under the chlorination process within the first $20 \mathrm{~min}$ and over the remainder of the study period. The addition of monochloramine to the chlorinated water system $(24 \mathrm{~h}$ after chlorination) resulted in the removal of coliforms and heterotrophic bacteria attached to pipe materials. Less than $1 \mathrm{cfu} \cdot \mathrm{cm}^{-2}$ viable bacterium (except for PVC) was observed on the surface of test pipes between 48 and $168 \mathrm{~h}$. However, the factor of time cannot be ignored in determining the effect of pipe materials on biofilm formation in potable water systems. Bacterial regrowth occurred on the surface of all pipe materials between 168 and $672 \mathrm{~h}$. The capability of bacterial regrowth occurring on the surface of test pipe materials during this period was linked to the depletion of the concentration of monochloramine residual.

Statistical evidence showed that the generic type of pipe materials greatly influenced the density of bacteria in laboratory-scale systems. Cement-based materials significantly supported less fixed bacteria than plastic-based materials (at $\mathrm{p}<0.05$ and $\mathrm{p}<0.01$ ). No significant difference in attached bacterial counts was found between the same generic types of pipe materials. This study suggests the use of cement and asbestos cement pipes for the distribution of chlorine-monochloramine treated water. Statistical evidence also showed that all physico-chemical parameters (temperature, $\mathrm{pH}$, turbidity, dissolved organic carbon, total nitrogen, sulphate) had no significant effect on bacterial number at $\mathrm{p}<0.05$, implying that the presence of an effective monochloramine residual in the chlorinated water system remains one of the most important factors in controlling the effect of pipe materials on biofilm formation.
\end{abstract}

Keywords: pipe materials, biofilms, chlorine, monochloramine

\section{Introduction}

The purpose of a water distribution system is to deliver to each consumer safe drinking water that is adequate in quantity and delivery pressure and acceptable in terms of taste, odour and appearance. The management of water quality in distribution systems is a major technological challenge to the water industry. Vigilance for any contamination and microbial degradation must be maintained. This is complicated by the very nature of the distribution system that is a dynamic network of mains, which are now available in a diverse range of materials (Block et al., 1993a). Pipe materials for water supply and distribution can generally be classified into one of three generic types: cementitious, metallic and plastic. A wide range of pressure pipe materials is available within these categories, and such materials are used in varying proportions across the countries of the world. Each of these materials has shown its technical advantages, but may also have technical and or economic limitations (Lion et al., 1988). The first stage in selecting pipe materials is a definition of the proposed application. This would require a knowledge of the operating conditions, including the hydraulic requirements (flow, pressure), aggressiveness of water ( $\mathrm{pH}$, alkalinity), external and internal

\footnotetext{
* To whom all correspondence should be addressed. 疋+2740 602 -2365; fax: +2740 653-1669; e-mail: mmomba@ufh.ac.za Received 29 July 2002; accepted in revised form 23 October 2003.
}

corrosivity, microbial contamination, soil loading, handling and joining under different topography, etc. (Lion et al., 1998).

It is well known that micro-organisms can colonise any surface in contact with water. Bacterial growth in a drinking water distribution system mainly occurs on the internal surface of the pipes. Detachment of bacteria from this biofilm may thus affect the water quality. Previous investigators have shown that bacterial growth occurring on pipe walls depends on different factors: concentrations of disinfectant (Momba et al., 1998; Momba and Binda, 2002), water temperature (Kaye and Nagy, 1999; Zacheus et al., 2000), pipe materials (LeChevallier et al., 1990) and concentration of biodegradable dissolved organic carbon (BDOC) which is the main substrate allowing bacterial growth in drinking water (Block et al., 1993; LeChevallier et al., 1993; Servais et al., 1995; Servais, 1996). The characteristics of the material composing pipes may greatly influence the densities of bacteria fixed in a distribution system. Studies have pointed out that the roughness of the material used for the distribution of potable water contributes to bacterial attachment (Pedersen, 1990; Percival et al., 1998). Pedersen (1990) compared biofilm development on stainless steel and PVC surfaces exposed to flowing municipal drinking water. After $167 \mathrm{~d}$ he measured a number of micro-organisms growing on the surface. Although there was no difference in the number of cells on the hydrophobic electron polished stainless steel and the hydrophobic PVC, the author reported that rougher stainless steel had 1.4 times more micro-organisms than electro-polished steel. Momba and co- 
workers (1998) reported a higher yield in viable bacteria on stainless steel coupons than on cement coupons during the first $8 \mathrm{~h}$ of their experimental study. Although smoother surfaces delay initial buildup of attached bacteria, smoothness does not significantly affect the total amount of biofilm that will attach to the surface. In general, on smooth surfaces, biofilms form at a slower initial rate than on rough ones, but biofilm formation after a period of days is inevitable (Van der Wende and Charaklis, 1990).

Piping materials on which micro-organisms cannot adhere have yet to be discovered (Mayette, 1992). Experimental studies have shown that biofilms attach to the inner surface of the distribution system even in the presence of free residual chlorine concentration higher than $2.5 \mathrm{mg} \cdot \ell^{-1}$ (De Beer et al., 1994; Momba et al., 1999; Momba and Binda, 2002). Zacheus and co-workers (2000) reported that ozonation had no effect on biofilm formation on polyvinyl chloride (PVC), polyethylene (PV) and stainless steel. Lund and Ormerod (1995) also found that ozonation and ultraviolet irradiation (UV) could not prevent biofilm formation on the surface of high-density polyethylene. Momba and co-workers (1998) reported the effectiveness of monochloramine in controlling biofilm regrowth on the stainless steel and cement surfaces when compared to chlorine, ozone and UV. In another study, Momba and Binda (2002) showed that a combination of chlorine and monochloramine provided an effective treatment for the inhibition of biofilm on the surface of stainless steel and galvanised mild steel as long as an effective monochloramine residual of 0.35 $\mathrm{mg} \cdot \ell^{-1}$ was maintained throughout the system. Chloramination as a second disinfectant was statistically proven to be the best and safest water purification process.

To be more efficient in the control of biofilms, a better understanding of the mechanisms involved in biofilm development, and especially those factors affecting the rate of bacterial colonisation and regrowth are necessary (Costerton et al., 1987). The present study is aimed at comparing the effect various pipe materials on biofilm formation in chlorine and combined chlorinemonochloramine treated water systems. During the study period, surface water was used as the water source; plastic-based (PVC, UPVC, MDPE) and cement-based ( $\mathrm{C}$ and $\mathrm{AC}$ ) materials were used as test pipes for the study of biofilms. The concentrations of inorganic and organic compounds in treated water systems were also taken in account. Using statistical analysis, a comparative study was performed. The study was planned to provide more information that could assist the South African water authorities to establish a regulation that will help drinking water producers to choose pipe materials, which could minimise the possibility of biofim development in an effort to improve the quality of potable water.

\section{Materials and methods}

\section{Identification of pipe materials}

A questionnaire relating to the type of pipe materials used in South Africa for the distribution of potable water, main disinfectant and initial dose used for the disinfection of drinking water, and problems linked to bacterial regrowth and biofilm formation in the distribution systems was designed and sent to 500 water treatment authorities. Data collected from this questionnaire revealed that 11 types of pipe materials are used in the following percentage: polyvinyl chloride-PVC (25\%), asbestos cement-AC (21\%), asbestos (19\%), unplasticised polyvinyl chloride-UPVC (16\%), steels $(8 \%)$, cement-C $(4 \%)$, bitumen coated $(3 \%)$, high density polyethylene-MDPE (2\%), copper $(1 \%)$, galvanised mild steel (1\%), mortar lined steel $(1 \%)$, cast iron $(1 \%)$. Data from the

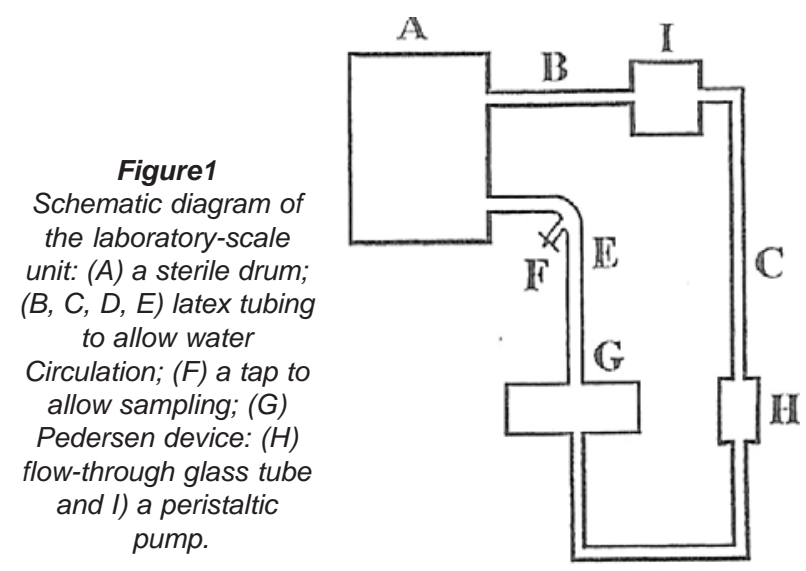

D

questionnaire also revealed that $84.2 \%$ of water treatment authorities use only chlorine (especially chlorine gas) as the main disinfectant. The initial chlorine dose used to disinfect the intake water remains unknown (65\%); mainly for rural water treatment plants. Moreover, the problem of bacterial regrowth and biofilm formation is well known only in urban water treatment plants (15.8\%) whereas $84.2 \%$ of the water treatment authorities in rural communities do not understand or ignore it due to the fact that no monitoring of the microbiological quality of water is performed in such water treatment plants. This study considered three plasticbased pipe materials (PVC, UPVC, MDPE) and two cement-based pipe materials (cement and asbestos cement).

\section{Test water source}

The experiment was performed using surface water from the Alice purification system. The Alice plant is a conventional water treatment plant (coagulation, hydraulic flocculation, sedimentation, filtration, chlorination), treating water from the Binfield Dam on the Tyume River. The coagulants are dosed at the same point just ahead of a $90^{\circ} \mathrm{V}$-notch weir and hydraulic jump. Powdered hydrated lime and granular alum are mixed with domestic water in separate dissolving/slurry tanks and then fed under gravity to the dosing point. Flash mixing results from the turbulence generated over the hydraulic jump. At the foot of the jump, the water enters a relatively short hydraulic flocculator before flowing to a threeway flow splitter. From the splitter the water flows to three horizontal settling tanks. Settled water overflows into a common channel, which flows to the filters. The filter influent is split between three $4.3 \mathrm{~m}$ diameter autonomous valveless sand filters. Chlorine gas is added to the combined filtrate just ahead of a $100 \mathrm{k} \ell$ in-plant reservoir. Water leaves the plant via a $900 \mathrm{~mm}$ line and enters the town's bulk distribution system. The test water was collected after filtration just before it reached the chlorination tank.

\section{Sampling of test waters}

Water samples were collected in four $50 \ell$ sterile polyethylene drums and one sterile bottle from the filtration tank. The water sample in the sterile bottle was used to check the initial bacterial counts in water. Before use, the drums were washed with the detergent, rinsed with hot tap water and distilled water, and then disinfected with $5 \mathrm{mg} \cdot \ell^{-1}$ of chlorine for $24 \mathrm{~h}$. Twenty-four hours after disinfection, sodium thiosulphate (ca $17.5 \mathrm{mg} \cdot \ell^{-1}$ ) was added to the drums to stop further chlorination and neutralise any disinfectant residual. The drums were then rinsed with sterile distilled water, after which a total microbiological count was done to check 
the sterility of the drum. Sample waters were then transported to the laboratory and analysis proceeded immediately.

\section{Laboratory-scale unit}

The experimental study was performed using the laboratory-scale unit (Fig. 1), described for the first time for the study of biofouling by Jacobs et al. (1996) and repeatedly used by Momba (1997) and Momba and co-workers $(1998,1999 ; 2000 ; 2002)$ for the study of biofilm in potable water systems. The laboratory-scale unit consisted of $1 \times 50 \ell$ polyethylene drum, which was attached in series to a peristaltic pump, a flow-through glass tube, a Pedersen device $(26 \times 10 \times 3 \mathrm{~cm})$ and a tap. All components were connected using latex tubing ( $8 \mathrm{~mm}$ diameter, $4 \mathrm{~m}$ length), which allowed the circulation of water in the system. The purpose of a flow-through glass tube was the visualisation of the biofilm. The Pedersen device was used to allow biofilm formation to be studied on plastic-based materials (PVC, UPVC and MDPE) and cement-based materials (Cement-C and Asbestos Cement-A/C). Twenty slides of each pipe material (plastic-based slides - $75 \times 25 \times 1 \mathrm{~mm}$; cement-based slides - 25 x $25 \times 10 \mathrm{~mm}$ ) were installed vertically into one Pedersen device. Prior to use, all four laboratory-scale units and the slides were treated in the same manner as the drums. Water circulated at a rate of $2.8 \ell \cdot h^{-1}$.

\section{Disinfection processes}

Prior to disinfection, the chlorine demand of the water was determined. The partially treated surface water (water after sedimentation and sand filtration) was disinfected with the initial free chlorine of $2.5 \mathrm{mg} \cdot \ell^{-1}$ prior to being transferred into four separate laboratory-scale units designed for the experimental study. Twentyfour hours after the circulation of the test waters in the different systems, $1.5 \mathrm{mg} \cdot \ell^{-1}$ monochloramine was separately added to the chlorinated water systems to form chlorine-monochloramine treated water. The monochloramine solution was prepared by reacting the chlorine solution with ammonium sulphate at $\mathrm{NH}_{4}$ : $\mathrm{Cl}$ mass ration of $4: 1$.

To obtain statistically meaningful results, two runs of the experimental study were done for the disinfected water. For each run, two water systems were disinfected with chlorine only and the other two systems with combined chlorine and monochloramine. The experimental study was conducted for a period of $672 \mathrm{~h}$ for each water system. Disinfected water samples were taken before the circulation of water in the laboratory-scale systems and after monochloramination and thereafter once a week for physicochemical and microbiological analyses. No neutralisation of any disinfectant in the laboratory-scale units was done during the experimental period, with the exception of samples on which microbiological analyses were conducted.

\section{Physico-chemical analyses}

Concentrations of initial and residual disinfectants (free chlorine and monochloramine) were measured using N, N-diethyl-p-phenylenediamine (DPD, Sigma) ferrous titrimetric method (APHA, 1998). Temperature, $\mathrm{pH}$ and turbidity were determined according to standard methods (Standard Methods, 1998). Calcium $\left(\mathrm{Ca}^{2+}\right)$, magnesium, $\left(\mathrm{Mg}^{2+}\right)$ chemical oxygen demand (COD), total nitrogen $(\mathrm{N})$, phosphate $\left(\mathrm{PO}_{4}^{3-}\right)$, sulphate $\left(\mathrm{SO}_{4}{ }^{2-}\right)$ concentrations were determined using the spectroquant NOVA 60 Manual (1998) and photometric test kits (Merck Laboraty Supplies (Pty) Ltd, South Africa). Samples for dissolved organic carbon (DOC) were pre- pared according to Mathieu et al., (1993). Sterile pre-treated glass bottles (pre-treatment: $200^{\circ} \mathrm{C}$ for $8 \mathrm{~h}$ ) containing the DOC samples were hermetically sealed, placed on ice and sent to the CSIR, Pretoria, South Africa, for the measurement of DOC concentrations.

\section{Biofilm analyses}

Biofilm experiments were conducted for the chlorinated water and the combined chlorine-monochloramine treated water. The colonised pipe slides were removed aseptically from the Pedersen devices. The removed slides were put into sterile plastic bottles with $20 \mathrm{ml}$ sterile MilliQ water. For each type of pipe materials, two slides $(75 \times 25 \times 1 \mathrm{~mm})$ were removed. To detach biofilms from the slide surfaces, the bottles were vortexed for 2 min using a vortex mixer (VM-3000, Millipore, South Africa). Attached coliform bacteria were enumerated by the membrane filtration procedure using the filter membrane with $0.45 \mu \mathrm{m}$ pore size and $47 \mathrm{~mm}$ diameter (Millipore). Membranes were placed on Chromocult agar (Merck), and all plates were incubated at $37^{\circ} \mathrm{C}$ for $24 \mathrm{~h}$. Analyses were carried out in triplicate. Heterotrophic plate count bacteria were enumerated by the standard plate spread method using R2A agar (Oxoid), incubated at $28^{\circ} \mathrm{C}$ for $7 \mathrm{~d}$ (Standard Methods, 1998). Analyses were carried out in duplicate. Attached bacterial counts were expressed in $\mathrm{cfu} \cdot \mathrm{cm}^{-2}$, and calculated using the following equation:

Attached viable count $\left(\mathrm{cfu} \cdot \mathrm{cm}^{-2}\right)=\mathrm{N}$ x D /surface area of slides where:

$\mathrm{N}=$ average number of colonies and
$\mathrm{D}=$ dilution factor.

\section{Statistical analyses}

To compare variations in treatments, ANOVA $( \pm=0.05)$ was applied to the bacterial counts with the latter as the dependent variable. The number of heterotrophic plate count bacteria was transformed by taking the logarithm base 10 to stabilise the variance. The numbers of the hours as well as the pipe materials were used to identify their effect of biofilm formation. A correlation was established between attached bacterial counts and disinfectant residual concentrations and between bacterial counts and the concentrations of organic and inorganic compounds in waters.

\section{Results}

\section{Microbiological features on slides}

\section{Coliform bacteria}

Figure 2 illustrates the results of a two-way ANOVA for the mean coliform bacterial counts when considering factors of time and pipe materials (polyvinyl chloride-PVC, unplasticised polyvinyl chloride-UPVC, medium density polyethylene-MDPE, cement and asbestos cement-AC) exposed to chlorine and chlorine-monochloramine treated waters.

Chlorinated water - The attachment of coliform bacteria on test pipes exposed to chlorinated water was apparent within $20 \mathrm{~min}$ (Fig. 2). Twenty-four hours after chlorination, an increase in coliform counts was observed on the surface of all pipes with a higher number on the cement pipe than on the other pipe materials (Fig. 2). The coliform counts progressively increased between 


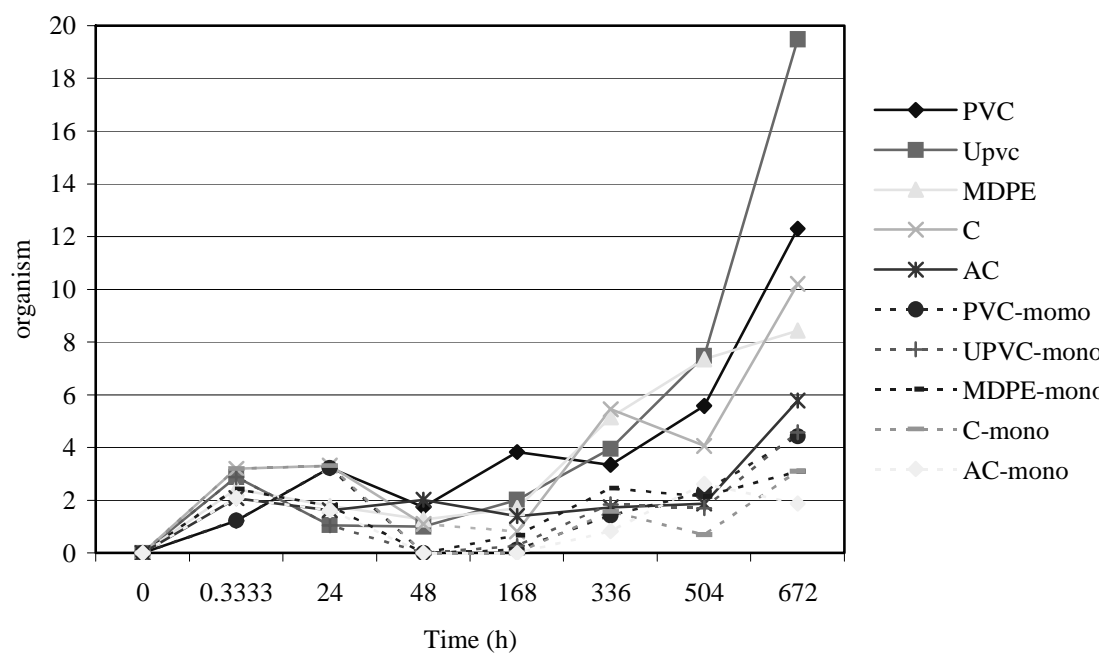

Figure 2

Mean counts of coliform bacteria $\left(\mathrm{cfu} \cdot \mathrm{cm}^{-2}\right)$ by time and pipe materials within chlorine $(0 h-672 h)$ and combined chlorine-monochloramine $(24 h-672 h)$ treated water systems

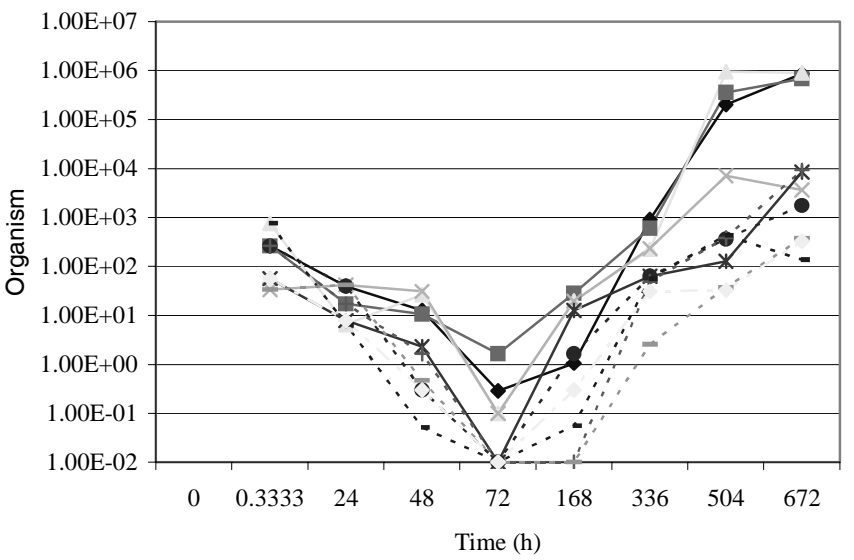

Figure 3

Mean of heterotrophic plate count bacteria $\left(\log \cdot \mathrm{cfu} \cdot \mathrm{cm}^{-2}\right)$ by time and pipe materials within chlorine $(0 h-672 h)$ and combined chlorine-monochloramine $(24 h-672 h)$ treated water systems

336 and $672 \mathrm{~h}$. Mean bacterial counts between 48 and $168 \mathrm{~h}$ were comparatively lower than those recorded between 336 and $672 \mathrm{~h}$ (Fig. 2). Across the pipes, the mean counts on $\mathrm{AC}$ and $\mathrm{C}$ pipes were significantly lower than those on PVC, UPVC and MDPE pipes at $\mathrm{P}<0.01$.

Combined chlorine-monochloraminated water system - The addition of $1.5 \mathrm{mg} \cdot \ell^{-1}$ mochloramine to the chlorinated water system resulted in the removal of coliform bacteria on the surface of all pipe materials between 24 and $48 \mathrm{~h}$, after which a gradual increase in bacterial counts occurred on PVC, UPVC and HDPE between 168 and $672 \mathrm{~h}$ (Fig. 2). Coliform regrowth on $\mathrm{C}$ and $\mathrm{AC}$ pipes exposed to the combined system occurred within $336 \mathrm{~h}$. Between 336 and $672 \mathrm{~h}$; the numbers of coliform bacteria reached 3 and $2 \mathrm{cfu} \cdot \mathrm{cm}^{-2}$ respectively. The mean bacterial counts were significantly lower on the cement-based pipe materials than on the plastic-based pipe materials at $\mathrm{p}<0.05$.

\section{Heterotrophic plate count bacteria}

The bacterial counts for HPC were transformed into log values to

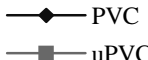

$\longrightarrow$ uPVC $\triangle-M D P E$ $\times-\mathrm{C}$ $\longrightarrow-\mathrm{AC}$ - - - PVC-Mono - + - uPVC-Mono - - - MDPE-Mono --- C-Mono AC-Mono

stabilise variances due to the extremely large count values. Figure 3 illustrates the results of a two-way ANOVA for the mean heterotrophic plate count bacteria when considering factors of time and pipe materials exposed to chlorine and chlorine-monochloramine treated waters.

Chlorinated water - An initial average density of $2 \log \mathrm{cfu} \cdot \mathrm{cm}^{-2} \mathrm{HPC}$ was recorded on PVC, uPVC and MDPE 20 min after chlorination of surface water, after which this number decreased to $1 \mathrm{log} \cdot \mathrm{cfu} \cdot \mathrm{cm}^{-2}$ between $20 \mathrm{~min}$ and $48 \mathrm{~h}$. Less than $1 \mathrm{log} \cdot \mathrm{cfu} \cdot \mathrm{cm}^{-2}$ was observed on the surface of plastic-based pipes between 48 and $72 \mathrm{~h}$. Because of bacterial regrowth, the remainder of the experimental study was characterised by a gradual increase of heterotrophic plate count bacteria on the surface of plastic-based materials. Between 24 and $672 \mathrm{~h}$, the average density of HPC bacteria on plastic-based materials was $5 \log \cdot \mathrm{cfu} \cdot \mathrm{cm}^{-2}$. A comparison between plastic-based pipes showed no significant difference in bacterial counts at $\mathrm{p}<0.01$. On cement-based pipes, an initial average density of $1 \log . \mathrm{cm}^{-2} \mathrm{HPC}$ was detected $20 \mathrm{~min}$ after chlorination, after which a decrease in bacterial counts occurred between 24 and $72 \mathrm{~h}$. Over the remainder of the study period, a maximum bacterial count of $3 \mathrm{log} \cdot \mathrm{cfu} \cdot \mathrm{cm}^{-2}$ was recorded on both $\mathrm{C}$ and AC. At $\mathrm{p}<0.01$, no significant difference was observed between these two pipe materials. However, a comparison between all pipe materials showed a lower significant HPC number on cementbased pipes than on plastic-based pipes at $\mathrm{p}<0.05$ and $\mathrm{p}<0.01$ (Fig. 3).

Chlorine-monochloramine treated water - Although attachment of bacteria was observed on all pipe materials within $20 \mathrm{~min}$ after chlorination, the addition of $1.5 \mathrm{mg} \cdot \ell^{-1}$ monochloramine in the chlorinated water system resulted in a gradual decrease of bacterial count. Less than $1 \mathrm{cfu} \cdot \mathrm{cm}^{-2}$ was observed on the surface of test pipes between 24 and $72 \mathrm{~h}$, after which the number of HPC bacteria progressively increased and reached the maximum total numbers of $3 \log \mathrm{cfu} \cdot \mathrm{cm}^{-2}$ and $2 \log$ HPC $\cdot \mathrm{cm}^{-2}$ on plastic-based pipes and cement-based pipes respectively (Fig. 3). Across the pipes, $\mathrm{C}$ and AC showed a statistically significant difference in mean counts of HPC bacteria compared to PVC, uPVC and MDPE at $\mathrm{p}<0.05$ and also at $\mathrm{p}<0.01$.

\section{Physico-chemical quality of test waters}

With the exception of DOC levels, the concentrations of inorganic compounds and the level of turbidity in all water systems reflected the limits allowed for potable water (Table 1). Compared to the initial water, an increased temperature value was noted in treated waters and this temperature was similar in all treated water systems (Table 1).

Although an initial concentration of chlorine $\left(2.5 \mathrm{mg} \cdot \ell^{-1}\right)$ was added to all four batch reactors to produce chlorinated water systems, a quicker decrease of the concentration of free chlorine 


\begin{tabular}{|c|c|c|c|c|c|c|c|c|}
\hline \multicolumn{9}{|c|}{$\begin{array}{l}\text { TABLE } 1 \\
\text { Physico-chemical values (range) of the test waters in different batch reactors }\end{array}$} \\
\hline \multirow{4}{*}{$\begin{array}{l}\text { Test } \\
\text { water }\end{array}$} & \multicolumn{8}{|c|}{ Parameters } \\
\hline & $\mathrm{T}\left({ }^{\circ} \mathrm{C}\right)$ & $\mathrm{pH}$ & NTU & $\underset{\left(\mathrm{mg} \cdot \ell^{-1}\right)}{\text { COD }}$ & $\begin{array}{c}\mathrm{DOC} \\
\left(\mathrm{mg} \cdot \ell^{-1}\right)\end{array}$ & $\begin{array}{c}\mathbf{N} \\
\left(\mathbf{m g} \cdot \ell^{-1}\right)\end{array}$ & $\begin{array}{c}\mathrm{PO}_{4}{ }^{3-} \\
\left(\mathbf{m g} \cdot \ell^{-1}\right)\end{array}$ & $\begin{array}{c}\mathrm{SO}_{4}{ }^{2-} \\
\left(\mathrm{mg} \cdot \ell^{-1}\right)\end{array}$ \\
\hline & \multicolumn{8}{|c|}{ Limit for no risk } \\
\hline & $<25^{\circ} \mathrm{C}$ & $6-9$ & $0-1$ & NS & $0-5$ & $0-6$ & NS & $0-200$ \\
\hline $\mathrm{WI}_{0}$ & $19-22$ & $6.1-7.3$ & $0.9-1.3$ & $4.0-4.8$ & $14.0-19.0$ & $0.6-1.2$ & $<0.5$ & $36-43$ \\
\hline BRPC & $19-22$ & $6.7-7.7$ & $0.3-0.8$ & $<4.0$ & $12.0-21.0$ & $0.6-1.8$ & $<0.5$ & $32-42$ \\
\hline BRCC & $19-22$ & $7.3-7.7$ & $0.3-0.8$ & $<4.0$ & $8.0-13.0$ & $0.8-2.1$ & $<0.5$ & $34-48$ \\
\hline BRPM & $19-22$ & $7.3-8.0$ & $0.4-0.9$ & $<4.0$ & $3.2-5.0$ & $0.5-1.9$ & $<0.5$ & $31-44$ \\
\hline BRCM & $19-22$ & $7.3-8.1$ & $0.3-0.9$ & $<4.0$ & $6.9-8.8$ & $0.5-2.0$ & $<0.5$ & $32-50$ \\
\hline & \multicolumn{8}{|c|}{ - Initial water; BRPC - Batch reactor with plastic } \\
\hline BRPM & \multicolumn{8}{|c|}{ _ Batch reactor with plastic slides in chlorine-monochloramine treated water system } \\
\hline BRCC & \multicolumn{8}{|c|}{ - Batch reactor with plastic slides in the chlorine water system } \\
\hline BRCM & \multicolumn{8}{|c|}{ - Batch reactor with cement slides in the chlorine-monochloramine treated water systems } \\
\hline
\end{tabular}

residual was noted in chlorinated water systems with plastic-based materials than in those with cement-based materials within the first $24 \mathrm{~h}$. Similar observations were also noted with the addition of monochloramine in the chlorinated water systems, despite a longer persistence of the residual monochloramine in both combined water systems (Fig. 4).

\section{Correlation between mean bacterial counts and the concentration of inorganic and organic compounds in test waters}

In chlorinated water systems, the temperature, DOC and total nitrogen showed weak negative correlations with coliform bacteria attached to plasticbased pipe materials and cement-based pipe materi-

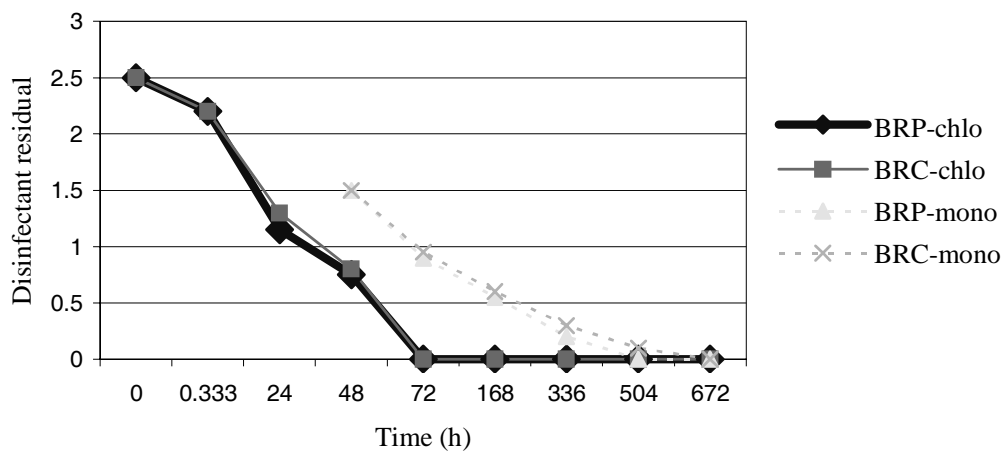

Figure 4

Decay of chlorine and monochloramine residuals (average values) in treated water systems als, while the $\mathrm{pH}$, turbidity and sulphate showed weak positive correlations. In both cases, these correlations were not significant at $\mathrm{p}<0.05$. Similar statistical observations were also noted in chlorine-monochloramine water systems although positive correlations were registered between mean counts of coliform bacteria and the values of temperature, $\mathrm{pH}$, turbidity and sulphate, and negative correlations were recorded for DOC and total nitrogen (Table 2).

With the exception of the turbidity and the sulphate, negative correlations were registered between the number of heterotrophic plate count bacteria attached to plastic and cement-based pipe materials exposed to both chlorine and chlorine-monochloramine treated water. Statistical evidence showed no significant difference between bacterial counts and physico-chemical parameters at $\mathrm{p}<$ 0.05 (Table 3).

\section{Correlation between mean bacterial counts and the} concentrations of disinfectant residuals in test waters Although negative correlations were registered between the concentrations of disinfectant residuals and the attached bacterial counts, the water treated with a combined chlorine-monochloramine disinfectant showed high correlation values compared to the water

treated with chlorine only, and the correlations were significant at $\mathrm{p}<0.05$ (Table 4).

\section{Discussion}

From the present study, important relations can be drawn; firstly between the formation of biofilm and the type of disinfection processes, and secondly between the density of fixed cells and the generic type of pipe materials.

General data indicated the colonisation of all test pipe materials by micro-organisms under chlorination (Figs. 2- 3). This biofilm included both coliforms and herotrophic plate count bacteria. The possibility of the cell attachment (especially within $20 \mathrm{~min}$ ) on the surface of test pipe materials exposed to chlorinated water is supported by weak correlations of free chlorine residual concentrations with bacterial numbers (Table 4). Statistically none of these correlations were significant at $\mathrm{p}<0.05$, which means, although there were inverse relations, these relations were not as significant as might have been expected. Bacterial biofilms developing in distribution systems receiving chlorinated water have been repeatedly reported by previous investigators (LeChevallier et al., 1987, 1988, 1990; Van der Wende and Characklis, 1990; Camper et al., 


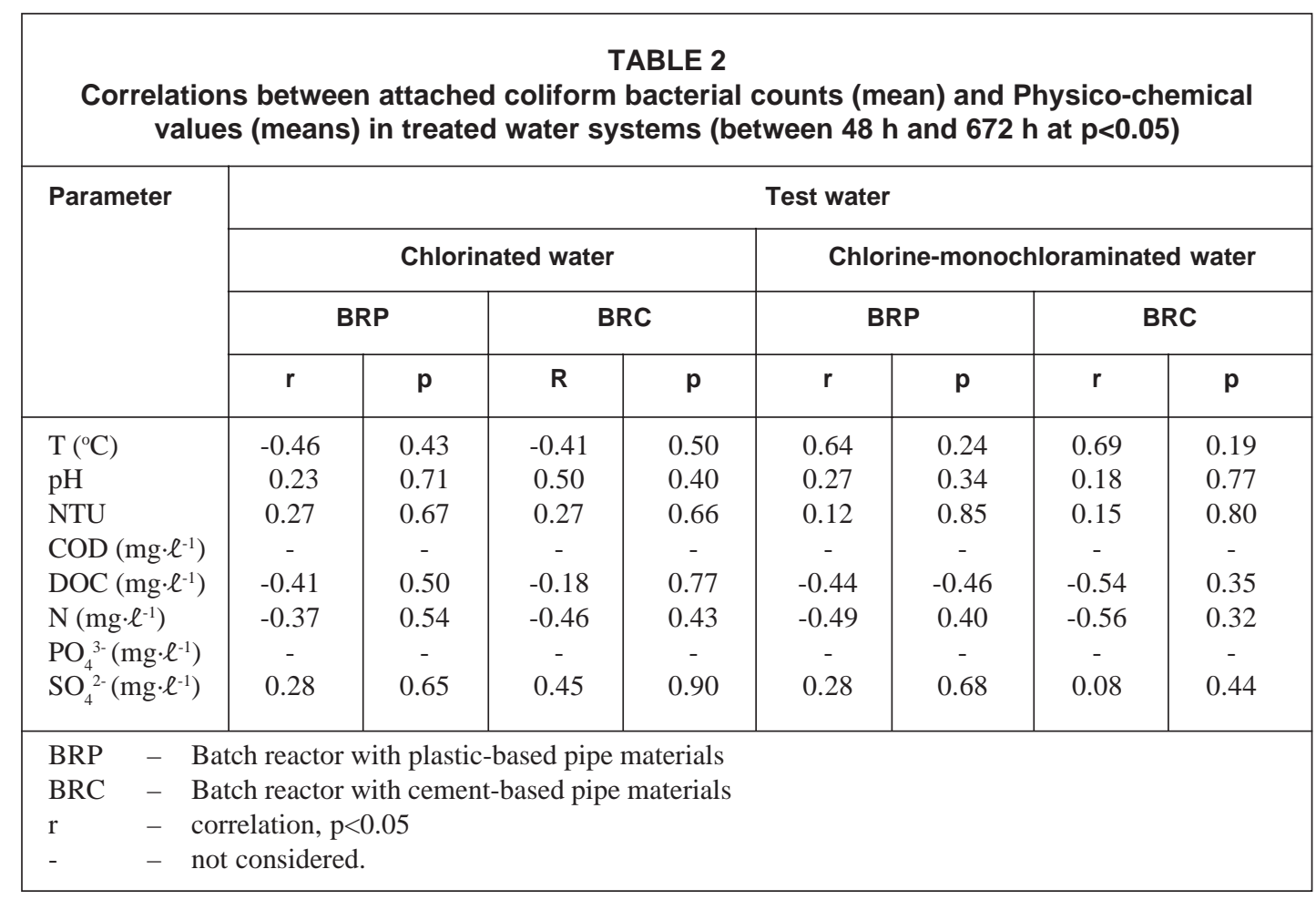

Mackey et al., 1998; Camper et al., 1999; Momba et al., 1999). The capability of $E$. coli to survive a high free chlorine residual dose of $0.7 \mathrm{mg} \cdot \ell^{-1}$ and to attach on pipe materials such as stainless steels was reported by Momba and coworkers in 1999. The authors pointed out that there were no significant differences in attached E. coli counts between the nondisinfected water and chlorinated water. The above findings clearly showed the ineffectiveness of free chlorine in inhibiting the formation of biofilm in potable water systems. Both coliforms and HPC bacterial groups may pose a significant public health risk. Promoting biofilm inhibition/removal directly or developing strategies for adequate control measures would therefore appear to be an attractive alternative approach for water industries.

During the experimental study, monochloramine was used as secondary disinfect-

1999; Momba et al., 1998,1999, 2000, 2002). Although the present investigation did not deal with the identification of various pathogenic and opportunistic pathogens, the survival and multiplication of heterotrophic bacteria such as Escherichia coli, Pseudomonas, Aeromonas, Klebsiella, Legionella spp., Mycobacterium, Campylobacter, Salmonella typhimurium and Helicobacter pylori have been observed within biofilms occurring in potable water systems with standard chlorine residual concentrations (Engel et al., 1980; Wadowsky et al., 1982; Burke et al., 1984; Armon et al., 1997; ant for the inhibition of biofilm formation in the chlorinated water system. Negative correlations were also found between monochloramine residual concentrations and attached bacterial numbers under the chlorine-monochloramine treatment. Compared to the chlorine treatment, these negative correlations were found to be much stronger and more significant (at $p<0.05)$ in the combined chlorine- monochloramine water system (Table 4 ). The strength of these negative correlations adds to the evidence of the effectiveness of monochloramine in the chlorinated water system, which was 
found prominent during the first 168 $\mathrm{h}$ of the treatment (Figs. 2-3). The occurrence of bacterial regrowth on the surface of test pipe materials during this period was linked to the depletion of the monochloramine residual concentration. At the decreased monochloramine levels, biofilm cells tended to increase at higher counts, hence affecting the microbiological quality of treated water within the distribution systems (Momba et al., 1998; 2000).

Although both treatments led to the formation of biofilms on the surface of test pipe materials, statistical evidence showed that a combination of chlorine and monochloramine remains an attractive approach for the removal and inhibition of bacterial biofilm in potable water systems. The study therefore suggests the implementation of the combined chlorine-monochloramine process in developing countries to ensure adequate control of the formation of biofilm in potable water distribution system. Because the disinfectant decays as water flows through the pipes, chlorinated water may again receive additional monochloramine doses at critical locations.

It is important to note that the generic type of pipe materials as well as the factor time greatly influenced the density of bacteria in treated water systems (Figs. 2-3). Cement-based materials (C and AC) support less fixed bacteria than plastic-based materials (PVC, uPVC and MDPE). This observation was also confirmed when using SEM techniques (Momba and Binda, 2002). Similar bacterial densities were then recorded on each generic type of test pipe. Statistical evidence showed no significant difference in fixed bacterial densities between cement and asbestos cement. Similar statistical trends were also observed when comparing PVC, uPVC and MDPE. This implies that pipe materials with similar porosity and roughness seem to support similar densities of fixed bacteria as also observed by Niquette and co-workers (2000). Compared to stainless steel, the lowest densities of bacteria fixed on cement exposed to chlorine, monochloramine, ozone, UV and hydrogen peroxide treated water have been previously recorded within $8 \mathrm{~d}$ of the experiment by Momba et al. (1998). Although the densities of bacteria fixed on cement-based materials increased with the exposure time, the highest bacterial counts were noted on the surface of plastic-based materials. Even if similar generic type of pipes alone could not show a statistically significant difference in bacterial counts, their interaction over time resulted in a significant difference in bacterial counts. This means that the time factor cannot be ignored in determining the effect of pipe materials on biofilm formation and also in devising a solution for the inhibition of biofilm in potable water distribution systems. Considering the time factor, the addition of monochloramine residual in the chlorinated water system at some critical locations might be recommended

r heterotrophic plate cour
TABLE 4 Correlations between attached bacterial counts (mean counts for coliform bacteria, mean
log counts for heterotrophic plate count bacteria) and the concentrations of disinfectant systems (between 48 and $672 \mathrm{~h}$ )

\section{Disinfectant residuals}

\begin{tabular}{|c|c|c|c|}
\hline \multicolumn{4}{|c|}{ Monochloramine } \\
\hline \multicolumn{2}{|c|}{ BRP } & \multicolumn{2}{c|}{ BRC } \\
\hline $\mathbf{r}$ & $\mathbf{P}$ & $\mathbf{R}$ & $\mathbf{p}$ \\
\hline-0.87 & 0.05 & -0.93 & 0.02 \\
-0.54 & 0.35 & -0.63 & 0.25 \\
\hline
\end{tabular}

BRP - Batch reactor with plastic-based pipe materials

every $168 \mathrm{~h}$ after the initial chlorine-monochloramine treatment.

The exposure time always depends on the distance between the treatment point and the end points. Power and Nagy (1999) reported that the Warragamba zone, a fully treated water system with short distances between the treatment point and the end points, experienced the least problems with bacterial regrowth when compared to other zones which contained dead end points between 20 and $41 \mathrm{~km}$. It would be therefore interesting in future work to determine some critical locations between the treatment point and the end points and to quantify the effect of the distance on biofilm regrowth after the addition of monochloramine in the chlorinated water system.

Other studies have shown a decrease in nutrients available for growth of micro-organisms in water distribution systems, implying the utilisation of substrates by micro-organisms (LeChevallier et al., 1987). During the present experimental study, the levels of organic and inorganic compounds were measured before and after the treatment of test waters in all batch reactors (Table 1). Although a decrease in the levels of certain physico-chemical parameters (pH, COD, DOC) was recorded, statistical evidence showed that all system parameters had no significant effect on bacterial numbers at $\mathrm{p}<0.05$ (Tables 2-3).

The findings of the present study clearly showed that the presence of an effective disinfectant residual in water distribution remains one of the most important factors that contribute to the control of bacterial biofilms. The generic type of pipe materials also plays a role in devising a solution to biofilm formation in potable water distribution system.

\section{Conclusions and recommendations}

This investigation indicated the colonisation of all test pipe materials (PVC, uPVC, MDPE, cement and asbestos cement) by coliforms and heterotrophic plate count bacteria within $20 \mathrm{~min}$ under chlorination treatment. The addition of monochloramine in the chlorinated water system resulted in the removal of coliforms and HPC attached to the pipe materials and less than $1 \mathrm{cfu} \cdot \mathrm{cm}^{-2}$ coliforms and heterotrophic plate count bacteria (except for PVC) was observed on the surface of test pipes between 48 and $168 \mathrm{~h}$. Statistical evidence showed that the generic type of pipe materials 
greatly influenced the density of bacteria in the water system. Cement-based materials (cement and asbestos) support less fixed bacteria than plastic-based materials (PVC, uPVC and MDPE). No significant difference in attached bacterial counts was found between the generic types of pipe materials. The time factor also cannot be ignored in determining the effect of pipe materials on biofilm formation in potable water distribution systems. Statistical evidence also showed that all system parameters (temperature, $\mathrm{pH}$, turbidity, dissolved organic carbon, total nitrogen, sulphate) had no significant effect on bacterial biofilms at $\mathrm{p}<0.05$, implying that the presence of an effective monochloramine residual in a chlorinated water system remains one of the most important factors in controlling the effect of pipe materials on biofilm formation. This study, therefore, recommends the use of cement and asbestoscement pipe for the distribution of chlorine-monochloramine treated water. Because the disinfectant decays as water flows through the pipes, chlorinated water may again receive an additional monochloramine dose at critical locations every $168 \mathrm{~h}$.

\section{Acknowledgements}

The authors are grateful to the Water Research Commission (WRC), Pretoria, South Africa for funding this study and Mr RA Agbandzi, Department of Statistics, University of Fort Hare for his assistance in statistical analyses.

\section{References}

ARMON R, STAROSVETZKY J, ARBEL T and GREEN M (1997) Survival of Legionella pneumophila and Salmonella typhimurium in biofilm systems Water Sci. Technol. 35 293-300.

BLOCK JC, DUTANG M, MAILLARD J and REASONER D (1993) Growth of attached bacteria in water distribution systems. In: Special Subject Biological activity in distribution systems. $19^{\text {th }}$ International Water Supply Congress, Budapest. pp S 1-8.

BURKE V, ROBINSON J, GRASEY M, PETERSEN D and PARTRIDGE K (1984) Isolation of Aeromonas hydrophila from a metropolitan water supply: Seasonal correlation with clinical isolates. Appl. Environ. Microbiol. 48 361-366.

CAMPER A, BURR M, ELLIS B, BUTTERFIELD P and ABERNATHY C (1999) Development and structure of drinking water biofilms and techniques for their study. J. Appl. Microbiol. Smp. Suppl. $858 \mathrm{~s}$.

COSRERTON JW, LADD GG, NICKEL JC, DASGUPTA MK and MARIE TJ (1987) Bacterial biofilms in nature and disease. Annu. Rev. of Microbiol. 41 43-464.

DE BEERS D, SRINIVASAN R and STEWART PS (1994) Direct measurement of chlorine penetration into biofilms during disinfection. Appl. Environ. Microbiol. 6 (12) 4339-4344.

ENGEL HWB, BERWALD LG and HAVELAAR AH (1980) The occurrence of Mycobacterium kansasii in tap water. Tubercle 61 21-26.

JACOBS L, DE BRUYN EE and CLOETE TE (1996) Spectrophotometric monitoring of biofouling. Water Sci. Technol. 34 (5-6) 533-540.

KAYE NP and NAGY AL (1999) Relationship between bacterial regrowth and some physical and chemical parameters within Sydney's drinking water distribution systems. Water. Res. 33 (3) 741-750.

LECHEVALLIER MW, BABCOCK TM and LEE RG (1987) Examination and characterization of distribution system biofilms. Appl. Environ. Microbiol. 53 (12) 2714-2724.

LECHEVALLIER MW, CAWTHON CD and LEE RG (1988) Factors promoting survival of bacteria in chlorinated drinking water supplies. Appl. Environ. Microbiol. 54 649-

LECHEVALLIER MW, LOWRY CD and LEE RG (1990) Disinfecting biofilms in a model distribution system. J. Am. Water Works Assoc. 82 87-99.

LECHEVALLIER MW, LOWRY CD and GIBBON DL (1993). Examining the relationship between iron corrosion and the disinfection of biofilm bacteria. J. Am. Water Works Associ. 85 111-123.
LION LW, SHULER ML, HSIEH KM and GHIORSE WC (1988) Trace metal interaction with microbial biofilm in natural and engineered systems. Environ. Control. 17 273-306.

LUND V and ORMEROD K (1995) The influence of disinfection processes on biofilm formation in water distribution systems. Water Res. 29 1013-1021.

MACKEY WG, GRIBBON LT, BARER MR and REID DC (1998) ParamPðtre controlant l'accumulation de bacteries dans les réseaux de distribution: Approche expérimentale. Séminaire Internationale. MatiPðre organique biodegradable ans les réseaux de distribution. Nancy.

MATHIEU L, BLOCK JC, NAILLANT J and REASONER D (1993) Control of biofilm accumulation in drinking water distribution systems. Water Suppl. 11 (3-4) 365-376.

MAYETTE DC (1992) The existence and significance of biofilms in water. Water Review, Water Quality Research Council, Lisle Il 1-3.

MOMBA MNB (1997) The Impact of Disinfection Process on Biofilm Formation in Potable Water Distribution Systems. Ph.D. Thesis, University of Pretoria.

MOMBA MNB, CLOETE TE, VENTER SN and KFIR R (1998) Evaluation of the impact of disinfection processes on the formation of biofilms in potable surface water distribution systems. Water Sci. Tech. 38 (8-9) 283-289.

MOMBA MNB, CLOETE TE, VENTER SN and KFIR R (1999) Examination of the behaviour of Escherichia coli in biofilms established in laboratory scale units receiving chlorinated and chloraminated water. Water Res. 33 (13) 2937-2940.

MOMBA MNB, CLOETE TE, VENTER SN and KFIR R (2000) Influence of disinfection processes on the microbial quality of potable groundwater in a laboratory-scale system model. J. Water SRT Aqua. 49 (1) 23-33.

MOMBA MNB and BINDA (2002) Combining chlorination and chloramination processes for the inhibition of biofilm formation in drinking surface water system models. J. Appl. Microbiol. 91 1-8.

NIQUETTE P, SERVAIS P and SAVOIR R (2000) Impacts of pipe materials on densities of fixed bacterial biomass in a drinking water distribution system. Water Res. 34 (6) 1952-1956.

PEDERSON K (1990) Biofilm development on stainless steel and PVC surfaces in drinking water. Water Res. 24 (2) 239-243.

PERCIVAL SL, KNAPP JS, EDYVEAN R and WALES DS (1998) Biofilm development on stainless steel in mains water. Water Res. 32 243-253.

POWER KN and NAGGY LA (1999) Relationships between bacterial growth and some physical and chemical parameters within Sidney's drinking water distribution system. Water Res. 33 (3) 147-150.

SERVAIS P, LAURENT P and RANDOM G (1995) Comparison of bacterial dynamics in various French distribution systems. Aqua $\mathbf{4 4}$ (1) $10-17$.

SERVAIS P (1996) Role du chlore and de la matière organique dans le controle de la croissance bacterienne en resaux de distribution de l'eau potable. Tribune eau 96 (2) 3-12.

STANDARD METHODS (1998) Standard Methods for the Examination of Water and Wastewater (20 $0^{\text {th }}$ edn.) American Public Health Association, American Water Work Association, Water Environment Federation. Washington, DC 20005- 2605.

VAN DER WENDE E and CHARACKLIS WG (1990) Biofilms in potable water distribution systems In: McFeters GA (ed.) Drinking Water Microbiology: Progress and Recent Developments, SpringerVerlag. New York. 249-268.

WADOWSKY RM, YEE RB, MEZMAR L, WING EJ and DOWLING NJ (1982) Hot water systems as sources of Legionella pneumophilla in hospital and non-hospital plumbing fixtures. Appl. Environ. Microbiol. 43 1104-1110.

ZACHEUS OM, IIVANAINEN EK, NISSINEN TK, LEHTOLA MJ, MARTIKAINEN PJ (2000) Bacterial biofilm formation on polyvinyl chloride, polyethylene and stainless steel exposed to ozonated water. Water Res. 34 (1) 63-70. 